\title{
The degree of peatland subsidence resulting from drainage of land
}

\author{
Antoni Grzywna ${ }^{1}$
}

Received: 20 April 2016/Accepted: 29 July 2017 /Published online: 14 August 2017

(c) The Author(s) 2017. This article is an open access publication

\begin{abstract}
The paper presents the degree of subsidence in stratigraphic transects and a change in soil morphology. The degree of subsidence was determined based on direct geodetic measurements taken in 1974 and 2012 and additionally with the use of empirical relationships of subsidence with the depth of drainage and peat properties. The histic horizon is built of peat thickness of $3 \mathrm{~m}$ on the Sosnowica and $0.64 \mathrm{~m}$ on the Uhnin. The value of subsidence of Histosol, measured by geodetic means, ranged from 9 to $33 \mathrm{~cm}$, while that of Gleysol from 0 to $4 \mathrm{~cm}$. The mean value of subsidence of the peatland in Sosnowica amounted to $24 \mathrm{~cm}$ over 38 years, which gives a degree of subsidence of $0.6 \mathrm{~cm} \mathrm{year}^{-1}$, i.e. a loss of peat mass amounting to $11.5 \%$ of the total resources. The situation is still worse in the case of the peatland in Uhnin, where mineralization and a fire of the peatland caused the peatland area to shrink by $36 \%$. The loss of peat mass, including loss due to fire, accounted for $53 \%$ of the total resources, which corresponds to a degree of subsidence of $0.35 \mathrm{~cm}$ year $^{-1}$. In engineering practice, the degree of subsidence can only be determined according to Jurczuk's formula taking into account environmental factors and the passage of time.
\end{abstract}

Keywords Drainage $\cdot$ Histosol $\cdot$ Subsidence $\cdot$ Geodetic measurements $\cdot$ Empirical relation

Antoni Grzywna

antoni.grzywna@up.lublin.pl

University of Life Sciences in Lublin, Lublin, Poland

\section{Introduction}

In Poland, there are 49,509 peat deposits with a total combined area of 1.255 million ha, which accounts for $29 \%$ of the country's wetlands area (4.35 million ha) and $4 \%$ of the country's terrain as a whole. More than $75 \%$ has been drained as a part of land improvement activities and is now used as grassland. The remaining non-drained peatlands occur mainly in forests and close to lakes.

The water retained in an undisturbed peatland is equivalent to $90 \%$ of its weight and $300 \%$ of its volume. Therefore, the more a peatland loses water, the more it loses volume. Drainage of water results in the process of subsidence of peat deposits, involving the densification and depletion of organic matter. The rate of subsidence of the surface of peatlands depends on the kind of peat, density of its mass, intensity of drainage and type of use (Gnatowski et al. 2010). When water which is normally retained in the pores of peat is drained, the structures dry out and shrink. It is possible that when peat dries it becomes hydrophobic and therefore is incapable of returning to the initial humidity levels (Holden et al. 2006). Van Seters and Price (2002) measured a total subsidence of $80 \mathrm{~cm}$ for a peatland in Quebec that had been drained for 57 years.

The degree of subsidence is correlated with the thickness of the peat column before drainage. An example of disappearance can be the peatlands on the River San, where after 79 years $77.4 \%$ of their area had disappeared, leaving barren mucky sands (Lipka et al. 2005). Murayama and Bakar (1996), for example, reported that subsidence rates in drained peatlands in Peninsular Malaysia, with bulk densities between 0.1 and $0.35 \mathrm{~g} \mathrm{~cm}^{-3}$, ranged from 2 to $4 \mathrm{~cm} \mathrm{year}^{-1}$ after initial drainage, and that subsidence decreased as bulk density increased. Dradjad et al. (2003) reported a subsidence range of 2.4 to $5.3 \mathrm{~cm}$ year $^{-1}$ over a 
14-year period, in peaty swamp soil about $2 \mathrm{~m}$ thick with a mineral content ranging from 73 to $86 \%$. Deverel and Rojstaczer (1996) also found a strong relationship between the content of organic matter in soil and subsidence rate in the Sacramento Delta with subsidence rates some 100 years after initial drainage having declined to less than $1 \mathrm{~cm}$ year $^{-1}$ in areas where organic content in the top soil was below $10 \%$, but still as high as $3.5 \mathrm{~cm} \mathrm{year}^{-1}$ where organic content was $60 \%$. Maximum land subsidence in the Venice Lagoon between 1.5 and $2 \mathrm{~m}$ has been observed over the past 70 years and a subsidence rate of the order of a few centimetres per year still occurs where peat soils outcrop (Gambolati et al. 2006; Zanello et al. 2011). Research by Deltares (Hooijer et al. 2012) has shown that in the tropics subsidence occurs very rapidly: in the 1 year after drainage peatland subsidence is typically 1 to 2 metres. In subsequent years, this stabilizes to a constant 3 to $5 \mathrm{~cm}$ per year, resulting in a subsidence of up to 1.5 metres within 5 years and 4-5 m within 100 years. In the Pomeranian Coastal Belt, the value of subsidence varied from 35 to $69 \mathrm{~cm}$ over 32 years (Jurczuk 2000), and in the Western Polesie, it ranged from 15 to $45 \mathrm{~cm}$ during a period of 26 years (Gawlik and Szajda 2003). In Rzeszów region in grassland conditions, the degree of subsidence was $0.82 \mathrm{~cm}$ year $^{-1}$, whereas in arable land it amounted to $1.68 \mathrm{~cm} \mathrm{year}^{-1}$ (Lipka et al. 2005).

Subsidence rates reported for a palm oil plantation in Malaysia, between 14 and 28 years after drainage, were $4.6 \mathrm{~cm} \mathrm{year}^{-1}$ on average at 17 locations for which water table depth data are not available (Wösten et al. 1997), and $3.7 \mathrm{~cm}$ year $^{-1}$ at 11 other locations with an average water table depth of $0.5 \mathrm{~m}$ (Hooijer et al. 2012). Andriesse (1988) suggested a stabilization of subsidence at long-term rates of up to $6 \mathrm{~cm} \mathrm{year}^{-1}$, based on observations in a number of locations in SE Asia. In the Everglades, USA, an average long-term subsidence rate of $3 \mathrm{~cm}$ year $^{-1}$ was reported after the initial years (Stephens et al. 1984), but this was for a different peat type in a sub-tropical region with a lower surface peat temperature of $25^{\circ} \mathrm{C}$. In peatland with an initial organic content of around $80 \%$ in the Sacramento Delta, California, subsidence after the initial 5 years proceeded at a constant rate of $7.5 \mathrm{~cm} \mathrm{year}^{-1}$ for over 50 years (Deverel et al. 2014).

The boggiest physiographic region is Western Polesie, where wetlands account for $42.1 \%$ of the total area. Particularly large shares of peatland are characteristic of the Łęczna-Włodawa Lakeland. In past centuries, the ŁęcznaWłodawa Lakeland was subject to systematic, continuously increasing anthropopressure. Dawidek et al. (2004) date the origins of land drainage works back to the eighteenth century. With reference to the Lakeland, Chmielewski et al. (2014) mentioned a significant development of the drainage system between World War I and II, among other things addressing the issue of closed-drainage areas. Drainage activities were carried out with particular intensity because after World War II many sites in the melting season were still barely accessible. The largest change in the water relations in history was connected with the construction of the Wieprz-Krzna Canal and of a dense system of drainage ditches between 1954 and 1973 (Gawlik and Szajda 2003).

The aim of the study was to analyse the degree of subsidence and changes in the structure of profiles of Histosol 50 years after drainage of peatlands in the valley of the River Piwonia. The paper presents the results of determining the degree of subsidence in two stratigraphic transects and change in the morphology of four soil profiles in 1974 and 2012 on a site that was drained in 1962. The paper aims to identify the applicability of empirical formulas in practice in order to determine the degree of subsidence.

\section{Materials and methods}

The object melioration of Piwonia-Uhnin is situated down the central section of the River Piwonia in the district of Parczew. The area lies at an elevation of $160 \mathrm{~m}$, in the physiographic region of the Western Polesie, eastern Poland. The study area is located in the central part in the 9th Podlasie agriculture climatic region (Bałaga 2007). Extensive reclamation works comprised construction of the Wieprz-Krzna Canal, regulation of the course of the River Piwonia and construction of a system of ditches. The total area of the site is 690 ha and the combined length of drainage ditches is ca. $10 \mathrm{~km}$. Within the site, two transects were selected for the purposes of the study: Sosnowica and Uhnin. The soils on the site are Histosol and Gleysol cover used as arable land and grassland.

The Sosnowica transect located near the village of Sosnowica is $760 \mathrm{~m}$ long and extends from the Wieprz-Krzna Canal (KWK) to the pond Hetman-51 $32^{\prime} 20^{\prime \prime} \mathrm{N}$, $23^{\circ} 04^{\prime} 30^{\prime \prime} \mathrm{E}$. On the left-bank area, there are meadows under intensive use, and on the right-bank area, there are meadows under extensive use. The water relations of the terrain are shaped by the deep-set Wieprz-Krzna Canal $(1.7 \mathrm{~m})$ and River Piwonia and by the network of ditches spaced from 70 to $100 \mathrm{~m}$ and from 0.8 to $1.0 \mathrm{~m}$ deep. At present, due to a periodic lack of water supply, a strong draining effect of the canal and the river can be observed (Grzywna 2011, 2012). The histic horizon in the Sosnowica transect built of peat deposit with a mean thickness of $3 \mathrm{~m}$. The largest thickness of peat deposit, i.e. $4.2 \mathrm{~m}$, is observed close to the river, and in the vicinity of the canal, it disappears completely. The area of the peatland is 114 ha, the volume of the histic horizon amounts to $2,280,000 \mathrm{~m}^{3}$, and its ash content is $11.3 \%$. It 
should be noted that within an area of 57 ha a gyttja horizon is deposited. Its volume is $670,000 \mathrm{~m}^{3}$.

The Uhnin transect located near the village of Uhnin is $824 \mathrm{~m}$ long is situated in a depression between arable lands and semi-natural meadows $-51^{\circ} 34^{\prime} 40^{\prime \prime} \mathrm{N}, 23^{\circ} 05^{\prime} 02^{\prime \prime} \mathrm{E}$. The area of the peatland is $28 \mathrm{ha}$, and the mean thickness of the histic horizon built of peat is $0.64 \mathrm{~m}$. The volume of the histic horizon amounts to $179,000 \mathrm{~m}^{3}$ with the ash content in the peat being $13.7 \%$. The water relations of the transect are shaped by a girdling ditch, with a depth of $1.3 \mathrm{~m}$, and a network of drainage ditches 0.8 deep, spaced at $100 \mathrm{~m}$.

The subsidence was determined on the basis of direct geodetic measurements taken in 1974 and 2012 and additionally using relationships of land subsidence with the depth of drainage and peat properties. The theoretical subsidence was calculated using the following formulas (Wösten et al. 1997; Jurczuk 2000):

- Ostromęcki $S=A \sqrt[3]{H D^{2}}$

- Wertz $S=K(0.08 H+0.066)$

- $\quad$ Segeberg $S=K D H^{0.707}$

- Mudd and Barret $S=A t \sqrt[3]{H D^{2}} g \sqrt{t / 8.525}$

- Jurczuk $S=0.0616 H^{0.319} P^{-1.835}(0.024 D-0.54)$ $t^{[1-\exp (-4.21 P)]}$,

where $S$ is settlement of the deposit (m), $H$ depth of the deposit $(\mathrm{m}), D$ depth of groundwater $(\mathrm{m}), t$ analysed period (years), $P$ bulk density $\left(\mathrm{g} \mathrm{cm}^{-3}\right)$, and $A$ and $K$ empirical factors.

The results were analysed using Excel. The significance of the correlation coefficient for the results of measurements and calculations of subsidence was estimated using the Student's $t$ test. In addition, the mean relative error for empirical formulas was determined. In environmental studies, the error value cannot be higher than $15 \%$.

\section{Results and discussion}

Based on the geodetic measurements taken in the selected transects in Sosnowica and Uhnin, the relief was determined (Fig. 1). The measurements, repeated after 38 years, provided grounds for determining the degree of actual subsidence of land. The geological composition of deposits was determined based on collected soil sampling in drilling sites.

The intensity of drainage is most often expressed in terms of the depth of ditches (Holden et al. 2006; Andersen et al. 2010). However, in drainage systems the depth of a ditch is not synonymous with the intensity of drainage. Undoubtedly such a measure is the groundwater table in the middle of the ditch spacing. In the Histosols in the Sosnowica transect, the mean groundwater table ranged from $52 \mathrm{~cm} \mathrm{(pt.} \mathrm{9)} \mathrm{to} 71 \mathrm{~cm}$ (pt. 5) and in the Uhnin transect from 47 (pt. 3) to $63 \mathrm{~cm}$ (pt. 6). Considerably greater depths of drainage were noted in the Gleysols where the mean groundwater level ranged from 74 to $122 \mathrm{~cm}$. Detailed data concerning the variations in the groundwater level in the years 2006-2009 are presented in works by Grzywna (2011, 2012).

The value of subsidence of Histosol in Sosnowica, measured using geodetic means, ranged from $9 \mathrm{~cm}$ at point 9 (near Hetman pond) to $33 \mathrm{~cm}$ at point 4 (near the Piwonia River). In the Uhnin transect, the values ranged from 13 to $30 \mathrm{~cm}$ in Histosol (fire of the peatland) and from 0 to $4 \mathrm{~cm}$ in Gleysol. The mean value of subsidence of the peatland in Sosnowica was $24 \mathrm{~cm}$ over the period of 38 years, which corresponds to a degree of subsidence of $0.6 \mathrm{~cm} \mathrm{year}^{-1}$, i.e. a loss of $262,000 \mathrm{~m}^{3}$ of peat volume (11.5\% of total resources). The situation is even worse in the case of peatland in Uhnin, where due to mineralization and a fire, the peatland area shrank by 10 ha (36\% of the area). In the remaining 18 ha, the mean value of subsidence amounted to $10 \mathrm{~cm}$, which corresponds to a degree of subsidence of $0.26 \mathrm{~cm}_{\text {year }}{ }^{-1}$. The loss of peat volume, including loss due to the fire, amounted to $95,000 \mathrm{~m}^{3}(53 \%$ of total resources), which corresponds to a degree of subsidence of $0.35 \mathrm{~cm}_{\text {year }}{ }^{-1}$.

In drilling 4, the murshic deposit thickness increased from 7 to $22 \mathrm{~cm}$, and the thickness of sedge peat deposit reduced from 67 to $21 \mathrm{~cm}$. Total subsidence amounted to $33 \mathrm{~cm}$, with the original histic horizon thickness being $4.2 \mathrm{~m}$. In drilling 9 of the sedge peat deposit, thickness decreased from 77 to $48 \mathrm{~cm}$ and a $15 \mathrm{~cm}$ murshic deposit thickness appeared. Here, the amount of subsidence was $9 \mathrm{~cm}$, with the original histic horizon thickness being $2.8 \mathrm{~m}$. In drilling 15, the sedge peat deposit disappeared and the thickness of the reed peat deposit reduced from 42 to $33 \mathrm{~cm}$. Originally, the histic horizon thickness was $0.75 \mathrm{~m}$. The subsidence value of $30 \mathrm{~cm}$ in this place is mainly a result of the peatland fire in 1992 . No changes at all were recorded in drilling 12 .

Changes in the structure of the soil profile, taxonomy and habitat conditions are presented using the example of 4 drillings - 4, 9, 12 and 15 (Fig. 2). In the Sosnowica transect, under conditions of moderate drainage, the Hemic Sapric Histosol transformed into Sapric Histosol (murshic) (pt. 4). The habitat changed from periodically medium dry to medium dry. Under the conditions of periodic irrigation (pt. 9), the Hemic Histosol transformed into Hemic Histosol (murshic), while the habitat changed from a wet to a periodically wet. Due to the small histic horizon, the changes in the Uhnin transect were of a different character. Here the Sapric Histosol (pt. 15), as a result of subsidence and a fire, transformed into the Histic Gleysol, and the habitat changed from medium dry to dry. Despite strong 

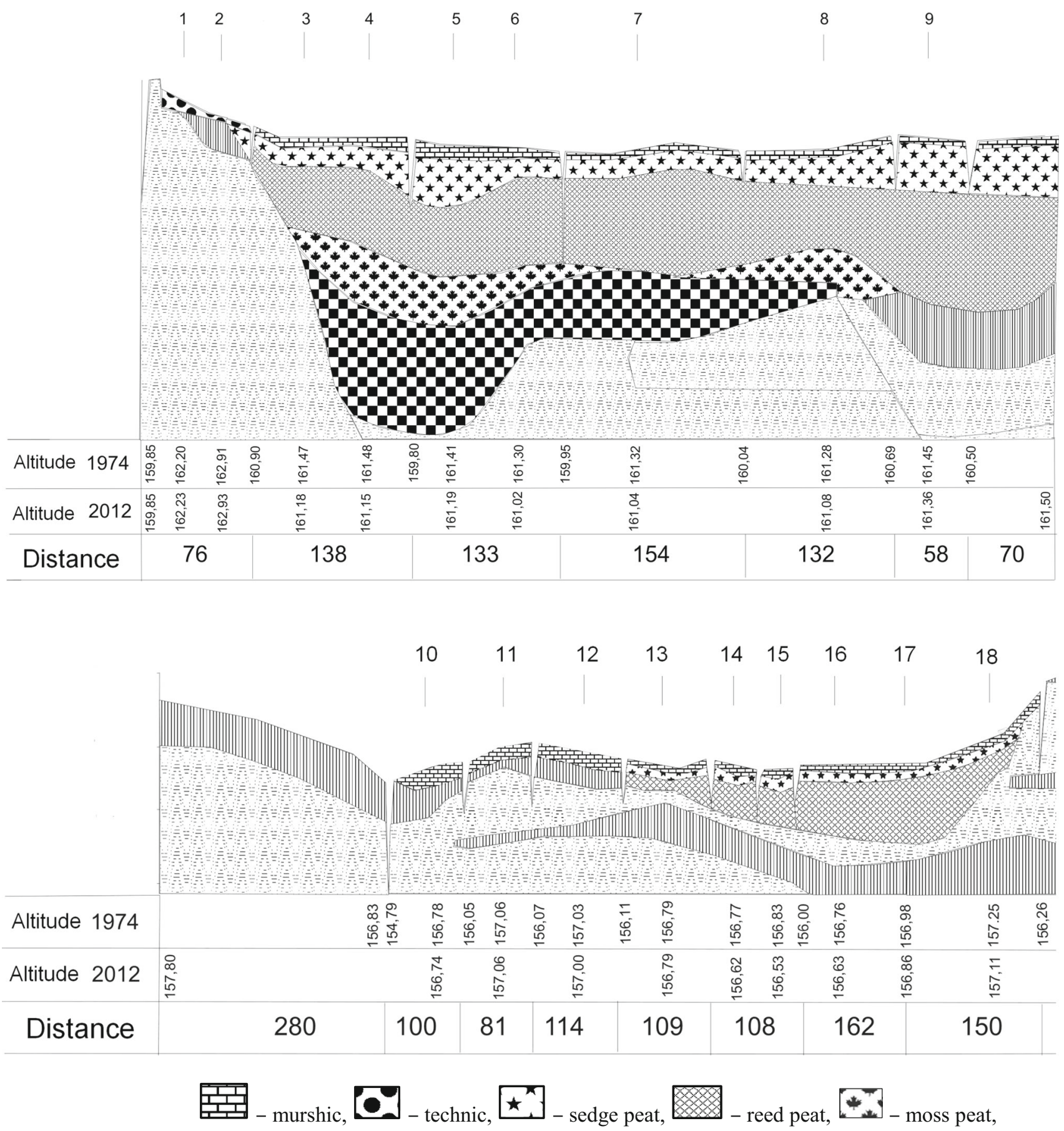



Fig. 1 Stratigraphic transect in Sosnowica and Uhnin

drainage, no changes occurred in the Mollic Gleysol (pt. 12)—habitat dry.

It has already been noted that drainage entails accelerated decomposition and oxidation of peat, which in turn increases peat density (Van Seters and Price 2002). These changes in peat have an impact on the carbon cycle and also change the rate of nutrient mineralization (Holden et al. 2004) and the redox potential (Sundstrom et al. 2000). The main factors affecting the natural course and intensity of peatland subsidence are the age of sediments, 
Fig. 2 Description of the morphological structure of soils (legend as in Fig. 1)

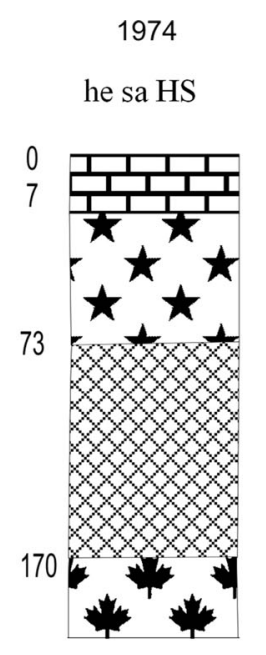

4

2012

sa HS dr


1974

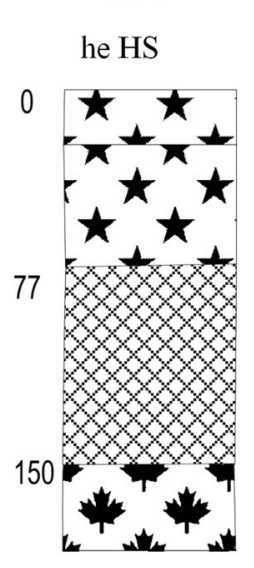

9

he HS dr
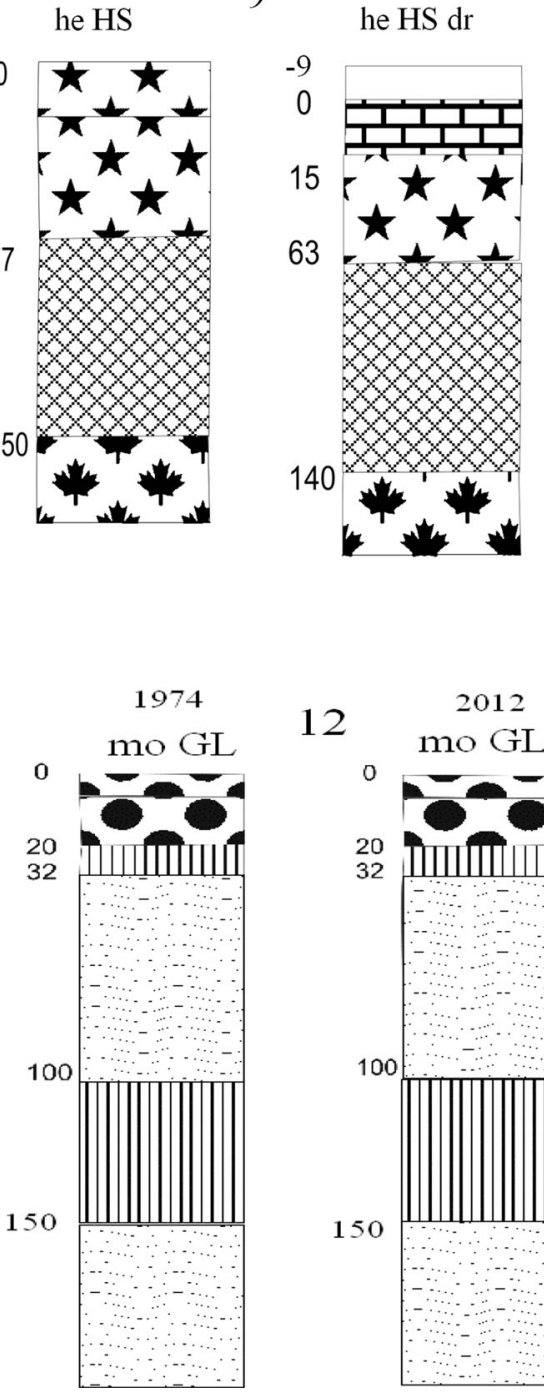

12

2012

12 mo GL

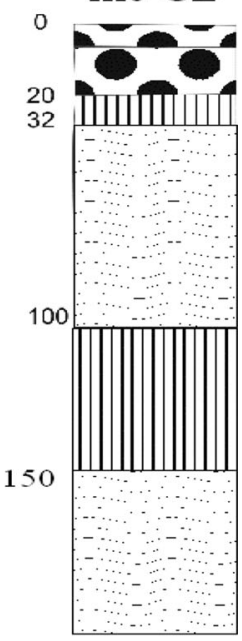

morphometric parameters, thickness of the deposit and climatic conditions. Natural factors are often modified by human interaction. Such factors of anthropogenic origin include drainage area, river regulation and agricultural development bogs (Keddy 2010; Leifeld et al. 2011; Zanello et al. 2011).

In Poland, the largest changes in the management of peatlands were made in the 1960s. At that time, a dense network of drainage ditches was designed in the PiwoniaUhnin site and the land was developed through the full crop method. From 1965 to 1990 , the land was also used as intensive grassland. In the 1990s, due to political changes, a shift to an extensive method took place. A decrease in the number of cows in 1995-2005 led to an abandonment of some lodging - resulting in wasteland. The decline in the groundwater level and extensive use is a common cause of a succession of plants and shrubs which like nitrogen.
Afterwards, an intensive process of mineralization and subsidence of Histosol began (Bałaga 2007).

Histosols are generally very difficult to cultivate because of poor drainage and often low chemical fertility. However, when formed on recent glacial lands they can often be very productive when drained and transformed into high-grade pasture for dairy or beef cattle. They can sometimes be used for growing fruit if carefully managed, but there is a great risk of the organic matter becoming dry powder and eroding under the influence of winds. A tendency towards shrinkage and compaction is also evident with crops. Drainage and intensive use of peatlands are the main factors causing the process which transforms peat into murshic-a granular or blocky structure. It is generally understood that the rate of subsidence varies depending on factors such as peat type, rate of decomposition, density and the 
Fig. 3 Relation between measured and theoretical subsidence. $R$ correlation coefficients, $B$ mean relative error, $W$ empirical formulas, $P$ geodetic measurements, solid line theoretical trend, dashed line real trend
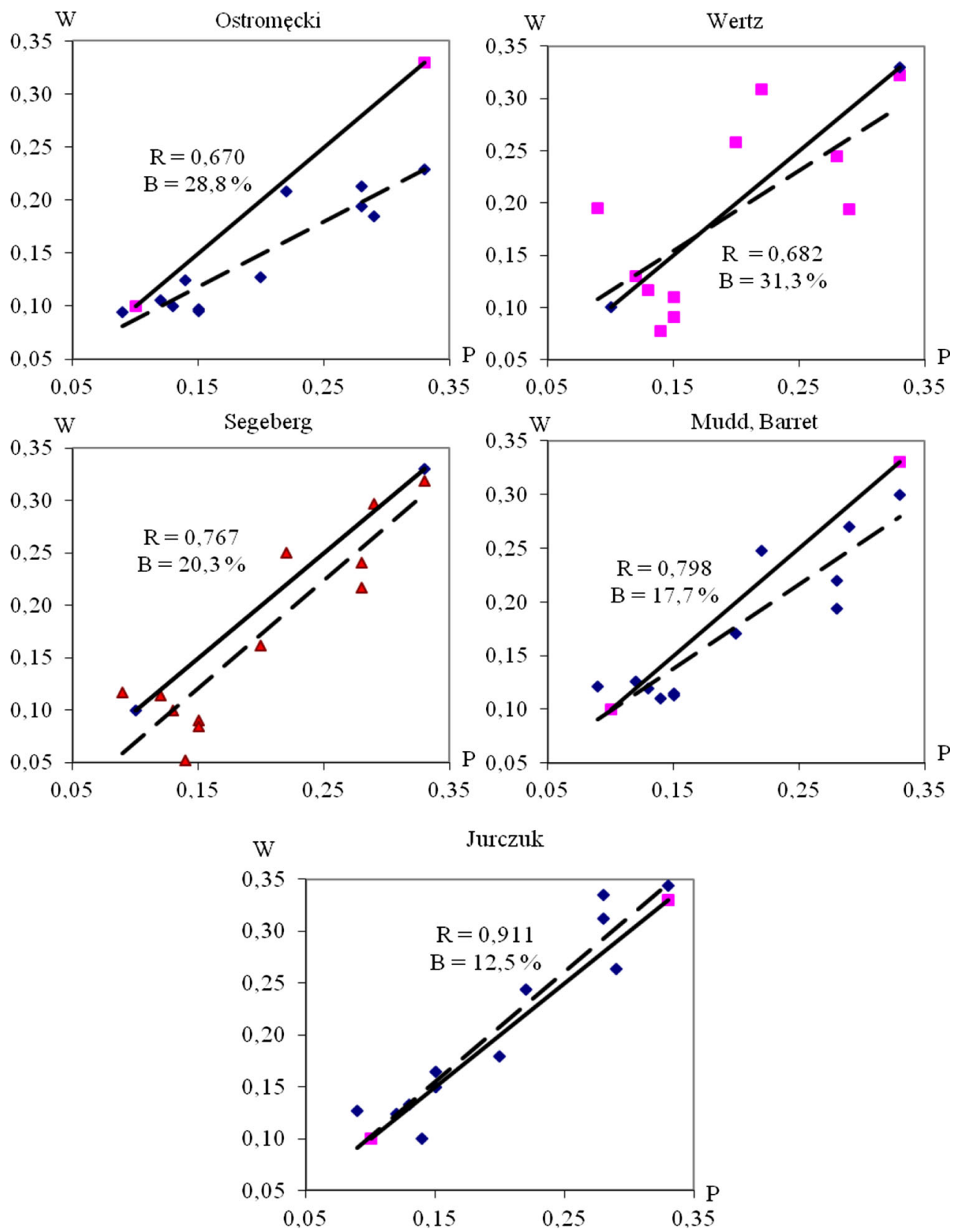

peat deposit thickness, drainage depth, climate, land use and period of drainage.

In order to estimate the suitability of data from five empirical formulas, the correlation coefficients $(R)$ and the mean relative error $(B)$ were determined with regard to the differences in the model and measured values of land subsidence. The smallest differences between measured and computed data were observed in the case of formula 5 (Jurczuk) where the mean relative error was $12.5 \%$ for deep peatland and for shallow peatland. The largest differences were recorded in the case of formula 2 where the error was $31.3 \%$ and formula 1 where the error was $28.8 \%$. For the analysed equations, the correlation coefficients ranged from
0.670 to 0.911 . In addition, Fig. 3 also includes lines of regression which facilitate the analysis of results. In the case of the analysed formulas $1-4$, the computed results differed significantly from the results of measurements at a confidence level of $\alpha=0.1$. This means that the formulas cannot be used for the whole transect simultaneously. The situation is much better in the case of respective points (Fig. 3). The mean relative error values were greater than the permissible value, and low significant correlation coefficients indicate a large divergence between the measured and the empirical values. Only based on Jurczuk's formula do the results not significantly differ from geodetic measurements (the mean relative error for formula does not exceed $15 \%$ ). 
Table 1 Actual subsidence period in years

\begin{tabular}{llllll}
\hline Point & Ostromęcki & Wertz & Segeberg & Mudd, Barret & Jurczuk \\
\hline 3S & 24.2 & 25.4 & 38.9 & 35.4 & 34.6 \\
4S & 26.4 & 37.1 & 36.7 & 34.5 & 39.6 \\
$5 \mathrm{~S}$ & 35.9 & 53.4 & 43.2 & 42.8 & 42.1 \\
$6 \mathrm{~S}$ & 28.9 & 33.3 & 32.7 & 29.9 & 45.5 \\
7S & 26.3 & 33.3 & 29.5 & 26.3 & 42.3 \\
8S & 24.1 & 49.0 & 30.8 & 32.5 & 34.0 \\
9S & 39.7 & 82.3 & 49.4 & 51.1 & 53.6 \\
1U & 33.7 & 21.2 & 14.1 & 29.9 & 27.1 \\
2U & 33.6 & 41.2 & 36.1 & 39.9 & 39.3 \\
3U & 29.2 & 34.2 & 29.2 & 34.8 & 38.9 \\
4U & 24.6 & 27.9 & 22.8 & 29.1 & 38.0 \\
5U & 24.1 & 23.1 & 21.3 & 28.6 & 41.5 \\
Mean & 29.2 & 38.4 & 32.1 & 34.6 & 39.7 \\
\hline
\end{tabular}

The empirical formulas were evaluated on the basis of the period after which an agreement was achieved between the empirical and measured values of land subsidence (Table 1). Adopting the groundwater level as the intensity of drainage, the period of attaining an agreement between the empirical and measured values was shorter for shallow peatlands with greater bulk density. Assuming a constant rate of subsidence in each transect, the formulas' yield periods differed from the actual ones. The mean time of subsidence calculated according to the formulas ranged from 29.2 to 39.7 years. Moreover, the first measurements were taken as late as 12 years after drainage, and the initial years are when the process of land subsidence is the fastest (Jurczuk 2000). Soil moisture conditions can be modified by irrigation and coverage. The analyses carried out by other authors showed that by maintaining the average level of groundwater at not more than $23 \mathrm{~cm}$, subsidence can be completely stopped (Grajewski et al. 2013; Brandyk et al. 2006).

\section{Conclusions}

This study aimed to determine the degree of subsidence in two stratigraphic transects and of the morphology in four soil profiles in the years 1974 and 2012 in Western Polesie (Poland). The following conclusions were drawn:

1. The values of the correlation coefficient and the relative error most frequently indicate the inapplicability of the tested mathematical formulas to determine the degree of land subsidence in the Piwonia-Uhnin site. In engineering practice, the degree of subsidence can only be determined using Jurczuk's formula taking into account environmental factors and the passage of time.

2. The mean value of subsidence calculated according empirical formulas was very close to the actually measured value. However, the formulas cover the period of 50 years from the time of drainage, while the measurements refer only to 38 years. The formulas presented in the paper are used for calculating land subsidence at the design stage of drainage projects; therefore, the depth of groundwater is synonymous with the intensity of drainage.

3. The analysed transects differ notably with regard to the extent of changes that have taken place. The degree of land subsidence is notably greater in the Sosnowica transect, which is primarily a result of the presence of thicker peat deposits. In the Piwonia-Uhnin site, the measured values of subsidence ranged from 9 to $33 \mathrm{~cm}$ over 38 years, which corresponds to a degree of subsidence of $0.35 \mathrm{~cm}_{\text {year }}{ }^{-1}$.

4. The moisture conditions, determined by the intensity of drainage, have an unquestionable effect on the degree of subsidence. In relation to subsidence, a change can be observed in the morphology of the soil profile. Under conditions of long-lasting moderate drainage, a granular or blocky structure was formed from a peat deposit. In the 50-year period after drainage, Sapric Histosol (murshic) dominates classified as a medium dry habitat.

Acknowledgements Studies were financed by budget funds allocated for science under research Project N N313 439239 in 2010-2013.

Open Access This article is distributed under the terms of the Creative Commons Attribution 4.0 International License (http://crea tivecommons.org/licenses/by/4.0/), which permits unrestricted use, distribution, and reproduction in any medium, provided you give appropriate credit to the original author(s) and the source, provide a link to the Creative Commons license, and indicate if changes were made.

\section{References}

Andersen R, Grasset L, Thormann MN, Rochefort L, Francez AJ (2010) Changes in microbial community structure and function following Sphagnum peatland restoration. Soil Biol Biochem 42:291-301

Andriesse JP (1988) Nature and management of tropical peat soils. FAO Soils Bulletin 59

Bałaga K (2007) Transformation of lake ecosystem into peat bog and vegetation history based on Durne Bagno mire (Lublin Polesie, e Poland). Geochronometria 29:23-43

Brandyk T, Oleszczuk R, Szatyłowicz J (2006) Comparison of different methods of water storage determination in peat-moorsh soil profile used as a meadow. Acta Agrophys 1:11-21 (in Polish) 
Chmielewski TJ, Kułak A, Michalik-Śnieżek M (2014) Method of retrospective evaluation of physiognomic landscape changes and its application in the West Polesie region (CE Poland). Reg Environ Change 14:1627-1639

Dawidek J, Sobolewski W, Turczyński M (2004) Transformations of catchment-areas of lakes converted into storage reservoirs in the Wieprz-Krzna canal system. Limn Rev 4:67-74

Deverel SJ, Rojstaczer DA (1996) Subsidence of agricultural lands in the Sacramento San Joaquin Delta, California: role of aqueous and gaseous carbon fluxes. Water Resour Res 32(8):2359-2366

Deverel SJ, Ingrum T, Lucero C, Drexler JZ (2014) impounded marshes on subsided islands: simulated vertical accretion, processes, and effects, Sacramento-San Joaquin Delta, CA USA. San Franc Estuary Watershed Sci 12(2):1546-1566

Dradjad M, Soekodarmodjo S, Hidayat MS, Nitisapto M (2003) Subsidence of peat soils - the tidal swamplands of Barambai, South Kalimantan. J Ilmun Tanah Lingkung 4(1):32-40

Gambolati G, Putti M, Teatini P, Stori GG (2006) Subsidence due to peat oxidation and impact on drainage infrastructure in a farmland catchment south of Venice Lagoon. Environ Geol 49(6):814-820

Gawlik J, Szajda J (2003) Changes in soil conditions on peatbogs in the region of the Wieprz-Krzna Canal due to drainage. Wiadomości Melioracyjne i Łąkarskie 3:167-170 (in Polish)

Gnatowski T, Szatyłowicz J, Brandyk T, Kechavarzi C (2010) Hydraulic properties of fen peat soils in Poland. Geoderma 154:188-195

Grajewski S, Miler AT, Krysztofiak-Kaniewska A (2013) Changes of ground water levels in the Zielonka Forest in period 1970-2009. Rocz Ochr Sr 15:1594-1611 (in Polish)

Grzywna A (2011) Changes of the groundwater table in the drainage site of Sosnowica in 2006-09. Gaz, Woda i Technika Sanitarna 11:259-260 (in Polish)

Grzywna A (2012) Changes of the groundwater table in the drainage site of Uhnin. Acta Sci Pol-Formatio 11(3):13-20 (in Polish)

Holden J, Chapman PJ, Labadz JC (2004) Artificial drainage of peatlands: hydrological and hydrochemical process and wetland restoration. Prog Phys Geog 28(1):95-123
Holden J, Evans MG, Burt TP, Horton M (2006) Impact of land drainage on peatland hydrology. J Environ Qual 35:1764-1778

Hooijer A, Page S, Jauhiainen J, Lee WA, Lu XX, Idris A, Anshari G (2012) Subsidence and carbon loss in drained tropical peatlands. Biogeosciences 9:1053-1071

Jurczuk S (2000) Effect of regulation of water relations on land subsidence and mineralisation of Histosol. Biblioteka Wiadomości IMUZ 96 (in Polish)

Keddy PA (2010) Wetland ecology: principles and conservation. Cambridge University Press, Cambridge

Leifeld J, Müller M, Fuhrer J (2011) Peatland subsidence and carbon loss from drained temperate fens. Soil Use Manag 27(2):170-176

Lipka K, Zajac E, Wdowiak W (2005) The impact of use on the disappearance of peat-moorsh soils in the valley of the river Mrowli near Rzeszów. Zeszyty Problemowe Postępu Nauk Rolniczych 507:349-355 (in Polish)

Murayama S, Bakar ZA (1996) Decomposition of tropical peat soils, estimation of in situ decomposition by measurement of $\mathrm{CO}_{2}$ flux. J Agric Res Quart 30:153-158

Stephens JC, Allen LH, Chen E (1984) Organic soil subsidence. Rev Eng Geol 6:107-122

Sundstrom E, Magnusson T, Hanell B (2000) Nutrient concentrations in drained peatlands along a north-south climatic gradient in Sweden. For Ecol Manag 216:149-161

Van Seters TE, Price JS (2002) Towards a conceptual model of hydrological change on an abandoned cutover bog, Quebec. Hydrol Process 16:1965-1981

Wösten JHM, Ismail AB, van Wijk ALM (1997) Peat subsidence and its practical implications: a case study in Malaysia. Geoderma 78:25-36

Zanello F, Teatini P, Putti M, Gambolati G (2011) Long term peatland subsidence: experimental study and modeling scenarios in the Venice coastland. J Geophys Res. doi:10.1029/ 2011JF002010 